Industrial Refrigeration 
There is a tendency in our complex (and complexed) time, to discount simplicity. People sometimes feel that a simple, straightforward solution to a problem, or a simple, understandable down-to-earth answer to a question must be rejected. Their basis for this surprising view appears to be that such a simple solution somehow reduces the magnitude of their problem, and by reflection, tends to minimise their own personal importance.

Brinsley Le Poer Trench

Temple of the Stars 


\title{
Industrial Refrigeration
}

\section{Principles, Design and Applications}

\author{
P. C. Koelet
}

with T. B. Gray

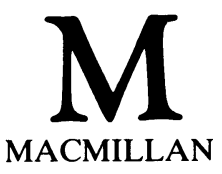


(C) P. C. Koelet 1992

Softcover reprint of the hardcover 1st edition 1992 978-0-333-52168-7

All rights reserved. No reproduction, copy or transmission of this publication may be made without written permission.

No paragraph of this publication may be reproduced, copied or transmitted save with written permission or in accordance with the provisions of the Copyright, Designs and Patents Act 1988, or under the terms of any licence permitting limited copying issued by the Copyright Licensing Agency, 90 Tottenham Court Road, London W1P 9HE.

Any person who does any unauthorised act in relation to this publication may be liable to criminal prosecution and civil claims for damages.

First published 1992 by

THE MACMILLAN PRESS LTD

Houndmills, Basingstoke, Hampshire RG21 2XS

and London

Companies and representatives

throughout the world

ISBN 978-1-349-11435-1

ISBN 978-1-349-11433-7 (eBook)

DOI 10.1007/978-1-349-11433-7

A catalogue record for this book is available from the British Library.

Typeset by TecSet Ltd., Wallington, Surrey 


\section{Contents}

Preface $\quad$ xi

Symbols and Units $\quad$ xiii

International Units $\quad \mathrm{xv}$

1 Principles of Refrigeration 1

1.1 History 1

1.2 Relationship between pressure and temperature 4

1.3 Energy 5

1.3.1 Internal energy 6

1.3.2 Internal energy in relation to compression and

1.4 Compression 8

1.5 Expansion 9

1.6 Enthalpy 10

1.7 Principles of the refrigeration process 11

1.8 The Mollier diagram or chart for refrigerants 15

2 An Introduction to Psychrometrics 22

2.1 Introduction 22

2.2 The gas laws 25

2.3 Relative humidity, $\mathrm{RH}$ or $\phi \quad 30$

2.4 Humidity ratio, specific humidity or moisture content $x$ or $g \quad 30$

2.5 Enthalpy of moist air 31

2.6 The factor $\mathrm{d} h / \mathrm{d} x \quad 31$

2.7 The wet-bulb temperature 31

2.8 The Mollier diagram for moist air 33

2.9 The slope of the cooling line 34 
2.10 The Carrier chart

2.11 The sensible heat factor $\quad 38$

2.12 The concept of bypassing $\quad 38$

2.13 The concept of apparatus dew point 39

3 Refrigerants 41

$\begin{array}{lll}3.1 & \text { Primary refrigerants } & 41\end{array}$

3.1.1 The refrigerant of the future 42

3.1.2 The choice of refrigerant 43

3.1.3 New refrigerants 46

3.2 Toxicity and other hazards $\quad 56$

3.3 The advantages of ammonia $\quad 59$

$\begin{array}{ll}3.4 & \text { Oil and refrigerant relationships }\end{array}$

$\begin{array}{lll}3.4 .1 & \text { Lubricating oils } & 63\end{array}$

$\begin{array}{lll}3.4 .2 & \text { Specific gravity } & 65\end{array}$

$\begin{array}{lll}3.4 .3 & \text { Viscosity } & 65\end{array}$

$\begin{array}{lll}3.4 .4 & \text { Viscosity index } & 65\end{array}$

$\begin{array}{lll}3.4 .5 & \text { Flash point } & 65\end{array}$

3.4.6 Pour point $\quad 66$

3.4.7 Floc point 66

3.4.8 Colour number $\quad 66$

3.4.9 Aniline point 66

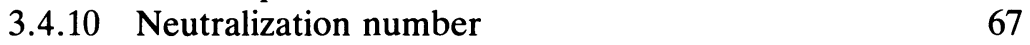

$\begin{array}{lll}3.5 & \text { Water in refrigerants } & 67\end{array}$

$\begin{array}{lll}3.6 & \text { Secondary refrigerants } & 69\end{array}$

$\begin{array}{lll}3.7 & \text { Heat-transfer characteristics } & 70\end{array}$

4 Compressors $\quad \mathbf{7 3}$

$\begin{array}{lll}4.1 & \text { Open and semi-hermetic compressors } & 73\end{array}$

$\begin{array}{ll}\text { 4.2 Compression action in the refrigeration process } & 74\end{array}$

4.3 Charge coefficient $\lambda$ - overall volumetric efficiency 79

4.4 Influence of compressor design on $\lambda \quad 83$

4.5 Power requirement of a piston compressor $\quad 84$

4.6 Influence of compressor design on $\eta_{\text {is }} \quad 86$

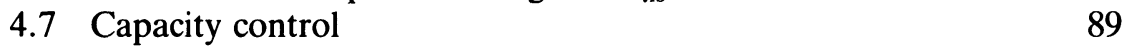

4.8 Main design features of a piston compressor 93

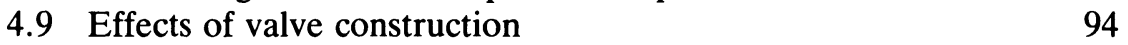

4.10 Calculation of cylinder swept volume $V_{\mathrm{s}}$ and number of
cylinders $a$

4.11 Multi-stage compression with open and closed intercooling 95

4.12 Determination of the intermediate pressure 98

$\begin{array}{ll}4.13 \text { Determination of discharge temperature } & 100\end{array}$ 
4.14 Determination of compressor speed and power consumption

4.14.1 Single-stage compression 101

4.14.2 Two-stage compression 104

4.15 Effects of evaporating temperature, condensing temperature, subcooling and superheating 106

4.16 Rotary compressors 109

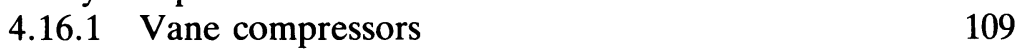

4.16.2 Screw compressors 110

$\begin{array}{lll}4.16 .3 & \text { Turbo-compressors } & 130\end{array}$

5 Evaporators and Condensers 132

5.1 Heat transfer 132

5.1.1 Heat transfer by conduction 133

5.1.2 Heat transfer by convection 135

5.1.3 Nusselt number (and other numbers) 138

5.1.4 Biot number 139

5.2 Evaporators: technology, design, selection and applications 139

5.3 Condensers 177

$\begin{array}{lll}\text { 5.3.1 Introduction } & 177\end{array}$

$\begin{array}{lll}\text { 5.3.2 Water-cooled condensers } & 178\end{array}$

$\begin{array}{ll}\text { 5.3.3 Evaporative condensers } & 181\end{array}$

5.3.4 Air-cooled condensers 184

$5.4 U$-values in daily practice 187

5.5 Modern developments in enhanced heat transfer for
evaporators and condensers

6 Vessel and Piping Design 191

6.1 Ammonia circuits 191

6.1.1 Two-phase flow 193

6.2 CFC circuits 194

6.3 Liquid separators, receivers, refrigerant pumps and
intercoolers

$\begin{array}{ll}\text { 6.3.1 Pump circulation } & 205\end{array}$

6.3.2 Oil separation in CFC installations 205

6.3.3 Pump selection and cavitation problems 206

6.3.4 Intercoolers 208

6.3.5 Calculation of the liquid separator zone

6.3.6 Separator liquid capacity 210

6.4 Air purging 215

6.5 Heat exchangers 217 
$\begin{array}{lll}6.6 & \text { Oil rectifiers } & 219\end{array}$

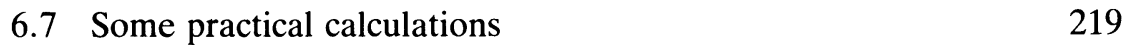

$\begin{array}{lll}6.7 .1 & \text { Capacity of a vessel } & 219\end{array}$

$\begin{array}{ll}\text { 6.7.2 The overflow valve } & 220\end{array}$

$\begin{array}{ll}\text { 6.7.3 The pressure relief valve } & 220\end{array}$

$\begin{array}{lll}6.7 .4 & \text { The hot-gas defrost line } & 220\end{array}$

6.7.5 Calculation of an oil rectifier in a R22 pump circulation

7 Controls

7.1 Applications in industrial refrigeration requiring regulation and control

7.2 Devices and components available to perform regulation and control

7.2.1 Thermostatic expansion valves 227

7.2.2 Pressure and temperature controls 229

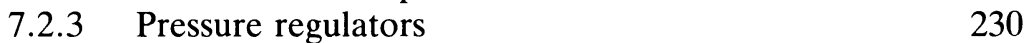

7.3 Condensing pressure control by flooding the condenser with liquid refrigerant

8 Food Products and their Preservation by Refrigeration 234

8.1 What are food products? 234

8.2 Vegetable matter 236

8.3 How plants live 237

8.4 Storage diseases 242

8.5 Meat products 243

8.6 How refrigeration techiques can help to conserve food products

8.7 Refrigeration or cooling 247

8.7.1 Determination of the cooling time 251

8.7.2 Half cooling time 253

8.8 Deep-freezing of food 254

8.8.1 Freezing spread 256

8.8.2 Freezing time calculation 258

8.8.3 Freezing equipment 263

8.9 Defrosting of frozen food 273

8.10 Packaging methods 277

9 Special Food Preservation Methods and Other Applications 280

9.1 Controlled atmosphere storage 280

9.1.1 Scrubbers 282

9.1.2 Burners 283

9.1.3 Controls 287

9.1.4 Ethylene scrubbing 289 
9.1.5 Vacuum cooling 290

9.1.6 Wet cooling system and flow-through cooling 292

9.1.7 Hypobaric cooling 295

9.2 Banana storage 296

9.3 Citrus fruit 299

9.4 Bakery products 300

9.5 Eggs 301

9.6 Ice cream 301

9.7 Chocolate products 305

9.8 Cheese 306

9.9 Beer 306

9.10 Deboned meat and prepared dishes (TV dinners) 309

9.11 Poultry 310

9.12 Fish 310

9.13 Refrigerated cargo 313

9.14 Ice plants 313

9.14.1 Block ice $\quad 313$

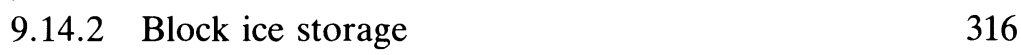

9.14.3 Slice or flake ice $\quad 316$

9.14.4 Slice ice storage 316

9.15 Other applications of artificial cooling 316

9.16 Heat recovery 320

10 Insulation Techniques and Coldstore Construction 322

10.1 Background information 322

10.1.1 Heat transfer 322

10.1.2 Water vapour diffusion, vapour barrier and

10.2 Insulation of coldstores 335

10.2.1 Floor insulation 335

$\begin{array}{ll}10.2 .2 & \text { Roof insulation } \\ 10.239\end{array}$

10.2.3 Gas-tight insulation 340

10.2.4 Overpressure protection 345

10.2.5 Practical guidelines to coldstore dimensioning 349

10.3 Pipework and vessel insulation 371

11 The Heat Load Calculation 374

11.1 Thermal transmission, $Q_{1} \quad 374$

11.2 Air infiltration, $Q_{2} \quad 374$

11.3 Moisture load, $Q_{3} \quad 378$

11.4 Product, $Q_{4} \quad 379$

11.5 Miscellaneous heat loads, $Q_{5} \quad 380$

11.6 Sample heat load calculation 381 
13 Plant Maintenance

13.1 Regular maintenance plans 396

$\begin{array}{ll}13.2 \text { Oil and refrigerant charges } & 398\end{array}$

13.2.1 Oil level 398

13.2.2 Refrigerant in the lubricating oil 399

13.2.3 Checking the refrigerant charge of the plant 400

13.2.4 Conversion from R12 and R502 to R22 401

13.3 Fault-finding and correction 403

13.3.1 Compressors 403

$\begin{array}{lll}13.3 .2 & \text { Oil } & 411\end{array}$

13.3.3 Expansion valve 414

$\begin{array}{lll}13.4 & \text { Standards } & 417\end{array}$

$\begin{array}{ll}\text { Epilogue } & 419\end{array}$

$\begin{array}{ll}\text { References } & 420\end{array}$

$\begin{array}{ll}\text { Bibliography } & 422\end{array}$

$\begin{array}{ll}\text { Glossary } & 423\end{array}$

$\begin{array}{ll}\text { Index } & 426\end{array}$ 


\section{Preface}

Refrigeration is an exciting application of science and technology. It involves a range of subjects such as thermodynamics, mechanics, electrical technology, civil engineering, hydraulics, aerodynamics, chemistry and, last but not least, food technology. However, it must never be forgotten that refrigeration is not an end in itself but the means to an end - in most cases, to help condition man's environment and satisfy many of his nutritional needs. During the past 100 years, refrigeration has become indispensable to our society. Modern food processing, storage and transportation, for instance, would be impossible without the help of refrigeration.

I am convinced that all over the world engineers and technicians would like to learn more about the subject, and for this reason I have written this book in English. It is intended for those who, either as contractors or consultants, are involved in the design of refrigeration plants, and for those who are responsible for the purchasing or maintenance of these plants.

Industrial applications are generally larger than commercial applications and normally require a qualified operator on duty. Industrial refrigeration plants are found in the food processing, plastic, metallurgical and chemical industries, and on board ship. Such systems are based on a centralized design and normally use open-type compressors with high efficiency, long lifetime and power consumption above $30 \mathrm{~kW}$.

This book deals not only with the installation and its components, but also with the products that are processed or stored in the refrigeration installation; it also considers the building in which the system operates.

The first chapters contain some useful and relevant thermodynamic background information. Later, a description of refrigeration and freezing systems is provided, as well as the calculation methods necessary to determine the refrigeration capacity and selection of the different components for the plant. This book is also about the application of refrigeration and therefore provides the reader with background information about the 
composition of and the optimum storage conditions for food products. Finally, it deals with the economic aspects, maintenance procedures, fault finding and repair.

Teachers and students in universities, polytechnics and technical colleges or others who would simply like to study refrigeration should find this book very useful.

I wish to thank everyone who was helpful in creating this book, especially my wife Mrs Maria Teresa Koelet-Paranhos de Oliveira for the extensive and difficult word processing and also Mrs Ilonka PerlChatterjee who, together with my wife, spent many hours editing the text.

I should also like to express my grateful thanks to Tom Gray for his painstaking work in helping to produce the final draft; his constructive comments have made a significant contribution throughout. Nonetheless, I remain ultimately responsible for any errors that may remain.

Last but not least I would like to acknowledge the assistance of all the individuals and companies quoted in the References at the end of the book.

PIETER C. KOELET

Meise, Belgium, 1991 


\section{Symbols and Units}

\section{Symbols}

$\begin{array}{ll}A \mathrm{~m}^{2} & \text { Surface } \\ a \mathrm{~m}^{2} / \mathrm{s} & \text { Temperature conductivity coefficient } \\ c, c_{\mathrm{p}}, c_{\mathrm{v}} \mathrm{kJ} /(\mathrm{kg} \mathrm{K}) & \text { Specific heat } \\ D \mathrm{~m}^{2} / \mathrm{s} & \text { Diffusion coefficient } \\ E \mathrm{~kJ} & \text { Energy } \\ E \mathrm{~kJ} / \mathrm{s}(=\mathrm{kW}) & \text { Energy flow } \\ F & \text { Force } \\ H \mathrm{~kJ} & \text { Enthalpy } \\ h \mathrm{~kJ} / \mathrm{kg} & \text { Specific enthalpy } \\ J \mathrm{~g} / \mathrm{m}^{2} / \mathrm{m} / \mathrm{s} & \text { Water vapour diffusion coefficient } \\ k & \text { Isentropic exponent } \\ k \mathrm{~W} /\left(\mathrm{m}^{2} \mathrm{~K}\right) & \text { Heat transmission coefficient } \\ L \mathrm{~kJ} / \mathrm{kg} & \text { Specific evaporation enthalpy } \\ l \mathrm{~kJ} / \mathrm{kg} & \text { Specific melting enthalpy } \\ M \mathrm{~kJ} / \mathrm{kmol} & \text { Relative molecular mass } \\ m \mathrm{~kg} & \text { Mass } \\ \dot{m} \mathrm{~kg} / \mathrm{s} & \text { Mass flow } \\ n & \text { Exponent of polytrop } \\ n 1 / \mathrm{s} ; 1 / \mathrm{min} & \text { Rotation number } \\ n \mathrm{kmol} & \text { Molecular quantity } \\ P \mathrm{~kW} & \text { Power } \\ p \mathrm{~Pa}=\mathrm{N} / \mathrm{m}^{2} ; \text { bar } & \text { Pressure } \\ Q \mathrm{~kJ} & \text { Heat load } \\ Q_{\mathrm{o}} \mathrm{kW} & \text { Refrigeration flow } \\ Q_{\mathrm{o}} \mathrm{kJ} / \mathrm{s}(=\mathrm{kW}) & \text { Heat flow } \\ q \mathrm{~kJ} / \mathrm{kg} & \text { Specific heat load } \\ q_{\mathrm{o}} \mathrm{kJ} / \mathrm{kg} & \text { Specific refrigerating load } \\ q_{\mathrm{o}}, v \mathrm{~kJ} / \mathrm{m}^{3} & \text { Volumetric refrigerant load } \\ & \\ & \end{array}$




\begin{tabular}{ll} 
xiv & \multicolumn{1}{c}{ Symbols and Units } \\
$R \mathrm{~kJ} /(\mathrm{kg} \mathrm{K})$ & Gas constant \\
$R \mathrm{~kJ} /(\mathrm{kmol} \mathrm{K})$ & Universal or absolute gas constant \\
$S \mathrm{~kJ} / \mathrm{K}$ & Entropy \\
$s \mathrm{~kJ} /(\mathrm{kg} \mathrm{K})$ & Specific entropy \\
$T \mathrm{~K}$ & Absolute temperature \\
$T_{\mathrm{c}} \mathrm{K}$ & Condensation temperature \\
$T_{\mathrm{e}} \mathrm{K}$ & Evaporation temperature \\
$T_{\mathrm{o}} \mathrm{K}$ & Room temperature \\
$T_{\mathrm{p}} \mathrm{K}$ & Product temperature \\
$t{ }^{\circ} \mathrm{C}$ & Temperature \\
$t \mathrm{~h}$ & Time \\
$U \mathrm{~m} / \mathrm{s}$ & Velocity \\
$U \mathrm{~kJ}$ & Internal energy \\
$V \mathrm{~m}$ & Volume \\
$V^{\prime} \mathrm{m} / \mathrm{s} ; \mathrm{m}^{3} / \mathrm{h}$ & Volume flow \\
$v \mathrm{~m} / \mathrm{kg}$ & Specific volume \\
$W \mathrm{~kJ} ; \mathrm{kW} \mathrm{h}$ & Work \\
$\alpha \mathrm{W} /\left(\mathrm{m}^{2} \mathrm{~K}\right)$ & Heat-transfer coefficient \\
$\beta \mathrm{kg} /\left(\mathrm{Pa} / \mathrm{m}^{2} / \mathrm{s}\right)$ & Matter transfer coefficient \\
$\delta \mathrm{m}$ & Thickness \\
$\epsilon \mathrm{kg} / \mathrm{kg} ; \%$ & Mass proportion \\
$\epsilon_{0}$ & Cold factor \\
$\eta \mathrm{Pa} \mathrm{s}=\mathrm{N} \mathrm{s} / \mathrm{m}^{2}$ & Efficiency coefficient \\
$\eta$ & Dynamic viscosity \\
$\lambda \mathrm{H} \mathrm{W} /(\mathrm{m} \mathrm{K})$ & Filling ratio \\
$\nu \mathrm{m} / \mathrm{s}$ & Thermal conductivity coefficient \\
$\pi$ & Kinematic viscosity \\
$\rho \mathrm{kg} / \mathrm{m}^{3}$ & Pressure ratio \\
& Density \\
&
\end{tabular}




\section{International Units}

The unit in which heat was expressed in the past was the calorie. $1 \mathrm{kcal}$ of heat was the quantity necessary to raise the temperature of $1 \mathrm{~kg}$ of water by 1 degree. This unit was used until the 1970s in continental Europe. Often the British Thermal Unit (Btu) was used in English-speaking countries, and 'tons of refrigeration' in the USA. There is now an internationally agreed system of units called the SI (Système International). In this system a quantity of heat is expressed in joules ( 1 calorie $=4.1868$ joules). The capacity of an installation is no longer expressed in calories $/ \mathrm{h}$, or in Btu, but in $\mathrm{kW}$. The International System defines the unit of temperature as the kelvin, rather than ${ }^{\circ} \mathrm{C}$ or ${ }^{\circ} \mathrm{F}\left(1^{\circ} \mathrm{C}\right.$ is equivalent to 1 kelvin, $0^{\circ} \mathrm{C}$ is 273.15 kelvin).

The SI or International System is based on six basic units plus two supplementary units. These are:

$$
\begin{array}{ll}
\text { Unit of length } & =\text { metre }(\text { symbol m) } \\
\text { Unit of mass } & =\text { kilogram }(\text { symbol kg) } \\
\text { Unit of time } & =\text { second (symbol s) } \\
\text { Unit of electric current } & =\text { ampere (symbol A) } \\
\text { Unit of temperature } & =\text { kelvin }(\text { symbol K) } \\
\text { Unit of luminous intensity } & =\text { candela }(\text { symbol cd) } \\
\text { Unit of plane angle } & =\text { radian }(\text { symbol rad) } \\
\text { Unit of solid angle } & =\text { steradian }(\text { symbol sr) }
\end{array}
$$

The system uses the same units for energy, no matter what kind of energy is being considered. 150 years ago Newton propounded his laws of motion: his 'second law' is often expressed by force is equal to mass multiplied by acceleration, or $F=m \times a$. In honour of his achievement 
the new unit of force is called the newton (symbol N). It is the force required to accelerate a body of $1 \mathrm{~kg}$ mass at $1 \mathrm{~m} / \mathrm{s}^{2}$. Previously, the unit of force was the pound or the $\mathrm{kg}$ :

$1 \mathrm{~kg}$ is the force that a body of $1 \mathrm{~kg}$ weight is subjected to by the pull of gravity at a certain point in Paris

$1 \mathrm{~kg}$ force $=\mathrm{kg}$ mass $\times 9.807 / \mathrm{s}^{2}=9.807 \mathrm{~N}$

The old system was confusing in as much as force and mass were both expressed in $\mathrm{kg}$. Also in an age of space exploration, units based on gravitational force at a certain point of a certain planet are not logical.

Pressure $=$ force $/ \mathrm{m}^{2}$. The unit of pressure is now $1 \mathrm{~N} / \mathrm{m}^{2}$, also called 1 Pascal (1 Pa). As this unit is small, for liquids and gases we use the unit 1 bar $=10^{5} \mathrm{~Pa}=10^{5} \mathrm{~N} / \mathrm{m}^{2} . \quad 1 \mathrm{~kg} / \mathrm{cm}^{2}$ in the old metric system $=9.807 \times 10^{4} \mathrm{~N} / \mathrm{m}^{2}=0.9807 \times 10^{5} \mathrm{~Pa}$.

The unit of energy is derived from work $=$ force $\times$ distance. Thus the unit of energy is $1 \mathrm{~N} \times 1 \mathrm{~m}=1 \mathrm{~N} \mathrm{~m}$. This unit is now called 1 joule $(1 \mathrm{~J})$. 1 joule is the work done by a force of $1 \mathrm{~N}$ when it moves $1 \mathrm{~m}$ in the direction of the force. The old $1 \mathrm{~kg}$ (force) $=9.807 \mathrm{~N}$.

$$
\begin{aligned}
& 1 \mathrm{~kg} \mathrm{~m}=1 \mathrm{~m} \times(1 \mathrm{~kg} \text { force } \times 9.807 \mathrm{~N} / \mathrm{kg} \text { force }) \\
& 1 \mathrm{~kg} \mathrm{~m}=9.807 \mathrm{~N} \mathrm{~m}=9.807 \mathrm{~J}
\end{aligned}
$$

$1 \mathrm{kcal}$ was $427 \mathrm{~kg} \mathrm{~m}$, which is $427 \times 9.807 \mathrm{~J}$ or $4,187 \mathrm{~J}$. Related to time, the old system used the unit of $\mathrm{kcal} / \mathrm{h}$. In the SI system, the unit of effort is the energy required to do work of $1 \mathrm{~N} \mathrm{~m}=1 \mathrm{~J}$ in 1 second. The $\mathrm{J} / \mathrm{s}$ is however called the watt (symbol W). We think $\mathrm{J} / \mathrm{s}$ but say ' $\mathrm{W}$ '.

$$
\begin{aligned}
& 1 \mathrm{kcal} / \mathrm{h}=\frac{4187}{3600} \mathrm{~J} / \mathrm{s}=1.163 \mathrm{~J} / \mathrm{s} \text { or } 1.163 \mathrm{~W} \\
& 1 \mathrm{kcal} / \mathrm{kg}=4187 \mathrm{~J} / \mathrm{kg}=4.187 \mathrm{~kJ} / \mathrm{kg}
\end{aligned}
$$

Specific heat is now expressed in $\mathrm{J} /(\mathrm{kg} \mathrm{K})$. Remember also that it is no longer permissible to use the metric unit of horse power (HP) but rather W or $\mathrm{kW}$ ( $1 \mathrm{HP}$ was $75 \mathrm{~kg} \mathrm{~m}$ or $0.736 \mathrm{~kW})$.

Kinematic viscosity $v: 1$ centistoke $=1 \mathrm{~m} \mathrm{~m}^{2} / \mathrm{s}$

Dynamic viscosity $\eta: 1$ centipoise $=1 \mathrm{~m} \mathrm{~Pa} \mathrm{~s}$ 
Speeds of revolution are no longer expressed as revolutions per minute (rpm):

$$
\begin{aligned}
& 1 \mathrm{rpm}=\pi / 30 \mathrm{rad} / \mathrm{s} \\
& 1 \mathrm{rad} / \mathrm{s}=30 / \pi \mathrm{rpm}
\end{aligned}
$$

Notwithstanding this, however, rpm are still used in this book. Experience has shown that few people in refrigeration technology use the new unit. In general, however, new units are being used routinely in many countries by refrigeration engineers. 